\title{
THE MINDSET OF PHYSICAL EXERCISE (PE) TEACHERS IN DISTRICT 134 UNPAS ON THEIR UNDERSTANDING OF PHYSICAL EDUCATION AFTER COMPLETING IN-SERVICE TEACHER EDUCATION AND PROFESSIONAL TRAINING (PLPG)
}

\author{
Akhmad Sobarna* \\ akhmadsobarna9@gmail.com* \\ STKIP of Pasundan west java of Indonesia*
}

This study is intended to describe the mindset of Physical Exercise (henceforth PE) teachers on physical education after completing in-service teacher education and professional training (henceforth PLPG). This study employed qualitative descriptive method. The population of this study is PE teachers in district 134 UNPAS that includes Karawang area, the city/the regency of Bogor, West Bandung regency, the city/the regency of Sukabumi, Cianjur, Purwakarta, Subang, Cimahi, and Bekasi. The sample of this study was 29 participants. The sample was drawn by means of incidental sampling method. The data collection instrumen used is rating scale mindset of the participants' understanding of physical education. The data was further analyzed by using descriptive analysis technique. The findings show that the level of understanding of the PE teachers about the implementation of reached $89 \%$ which belong in the criterion 'very good'. The description of every indicator demonstrates that: a) the perception of physical exercise teaching as much as $88,5 \%$ is categorized as good, b) physical education knowledge is considered as good as much as $89,5 \%$, c) the effort to enhance teaching skills is 79,3\%, which belongs in the criterion 'good'. In conclusion, generally, the mindset of the participants in district 134 UNPAS in understanding the aspect of physical education implementation reached $89 \%$ with the criterion 'very good'. This implication of this study is that in the implementation of $P L P G$, the emphasis should be paced upon enhancing understanding of physical education concept and the effort to hone the ability in teaching physical exercise in creative and innovative fashion.

Keywords : Mindset, PE teacher, PLPG district 134

Teachers' competency standards are defined as a measure which is established or required in the form of knowledge mastery, behaviour and actions of a teacher in order to be considered worthy to assume functional positions in accordance to the teracher's duties, qualifications, and educational background. Teachers' competency standards consist of three intertwined components, namely (1) teaching and learning management, (2) professional 
development, and (3) academic mastery. The competency standards are founded on attitude and character necessary to support the implementation of teachers' duties as professionals.

Each of the three components comprises of two skills. As a result, the three components involve 7 competencies, which are: (1) lesson planning, (2) the teaching and learning implementation, (3) evaluation of the students' achievements, (4) the implementation of follow-up towards the evaluation of the students' achievements, (5) professional development, (6) understanding of pedagogy, (7) academic content mastery.

Teachers' competency standards have multiple purposes and benefits. Teachers' competency standards are aimed to yield objective reference in measuring teachers' performance in order to obtain a guarantee of quality teaching and learning processes. In addition, teachers' competency standards are beneficial to: (1) serve as a benchmark for all shareholders in the field of education in order to provide teachers with training, quality improvement and career development, (2) improve teachers' performance in terms of creativity, innovation, skills, autonomy, and responsibilities in accordance with their professional position. Up to this day, only $50 \%$ of teachers in Indonesia possess standards and competency. Such a condition is does not confer significant contributions to improve the quality of our education. Another fact stated by the Ministry's Directorate General for Teacher Quality Improvement (PMPTK) is that a number of teachers had the score zero for the materials of the subject that they actually teach to their students. Such a fact was revealed based on competency test administered to teachers in 2004. In national scale, the mastery of content by teachers does not reach $50 \%$ of all the knowledge content that makes up teachers' competence, including Physical Exercise subject.

As a matter of fact, a teacher is obliged to possess academic qualifications, teacher certification, physically and psichologically health and the ability to relaize national education goals. The minimum academic qualification for a teacher is a bachelor's degree or a diploma degree proven by a certificate in accordance with the major, degree, and formal education unit of the designated workplace. Therefore, one of the government efforts to improve teachers' competency is by holding in-service teacher education and professional training program $(P L P G)$. In the implementation of $P L P G$, the participants are demanded to do numerous things related to enhancing the quality of education as expected from a teacher. In turn, the participants with all the efforts and preparations have to be able to adjust 
themselves and perform a major breakthrough to be a teacher that complies the regulations stipulated by the government.

Similarly, PE teachers have to be able to master the concept of physical education thoroughly in order for it to be implemented in teaching and learning PE with true educational objectives by means of physical activities. As mentioned in a study conducted by Patrie, K \& Mcdee, C., stating that Professional development (PD) for physical teachers is recognized as a key vehicle through which to improve teaching and, in turn, to improve student achievement. Professional development is also a way to introduce curriculum and pedagogical reforms. It means that professional development of teachers is the key to enhance the quality of PE teaching and the success of students in learning it. Professional development of teachers can also adjust pedagogical skills with the prevailing curriculum.

Through PLPG, PE teachers are expected to develop professionalism in teaching PE in their schools, change the mindset of their understanding of physical education ranging from implementing teaching styles, approaches, strategies, and models that suit the students' characteristics, to providing PE facilities and equipment that are creative and innovative to support meaningful learning for students. Based on the aforementioned problems, this study focuses on describing the mindset of PE teachers on their understanding of physial education that have completed PLPG.

\section{METHOD}

This study is a qualitative descriptive research. According to Sugiyono, descriptive research generally is a non-hypothesis study, therefore, it does not involve formulating a hypothesis. Thus, this study does not attempt to test a particular hypothesis, but to describe a variable, an phenomenon, or a situation as it naturally occurs. This research is intended to describe the mindset of PE teachers that joined PLPG in district 134 UNPAS on their understanding of physical education.

Data collecting instrument is the gauge of the scrutinized phenomenon based on existing facts in the participants. The instrument in this study is mindset rating scale which was used to reveal the mindset of PE teachers in disrict 134 UNPAS on their understanding of physical education after completing $P L P G$. The validity and the reliability of the mindset rating have been previously measured. The rating scale yielded scores which was analyzed by using percentages. 
The population of this study is PE teachers in district 134 UNPAS that includes Karawang area, the city/the regency of Bogor, West Bandung regency, the city/the regency of Sukabumi, Cianjur, Purwakarta, Subang, Cimahi, and Bekasi. The sample of this study is 29 teachers drawn from the population. The sampling technique used in this study is incidental sampling in which the sample was drawn based on incidents, by chance, or anyone from the population who coincidentally met the researcher after PLPG.

The technique of data collection was by distributing rating scale to the sample and participants and they were directly asked to complete the rating scale based on their understanding at the time after PLPG finished on November 24th 2015. Afterwards, all the rating scales were collected and they were scored. The technique of data analysis employed in this study is descriptive analysis technique. In order to calculate the percentages of the participants' responses that belong in particular categories in each aspect, the following calculation mechanism was used :

$$
\mathrm{P}=\frac{f}{n} \times 100 \%
$$

$\mathrm{P}=$ Percentage

$\mathrm{F}=$ Frequency

$\mathrm{N}=$ The number of the sample

After the scores are onverted into percentages, they were further categorized to find out the elevel of peadagogic competency. The formula is as follow

0 = bila samasekali belum tahu

$1=$ telah mengetahui sampai $25 \%$

$2=$ telah mengetahui sampai $50 \%$

$3=$ telah mengetahui sampai $75 \%$

$4=$ telah mengetahui $100 \%$

\section{RESULTS}

The result of the study indicates the mindset of PE Teachers in district 134 UNPAS on their understanding of physical education which is based on perception items on their understanding on physical education, knowledge of physical education and the efffort to improve teaching skills in physical education. Based on the data collected and analyzed in 
desriptive manner, overall it shows that the mindset of the PE teahers' understanding in the implementation of physical education in their schools gained $89 \%$ which was yielded from a set of data as many as 1708 from 29 participants and it was divided by 1914 from the overall score of the predefined criteria. Such a result can be categorized in the following continuum.

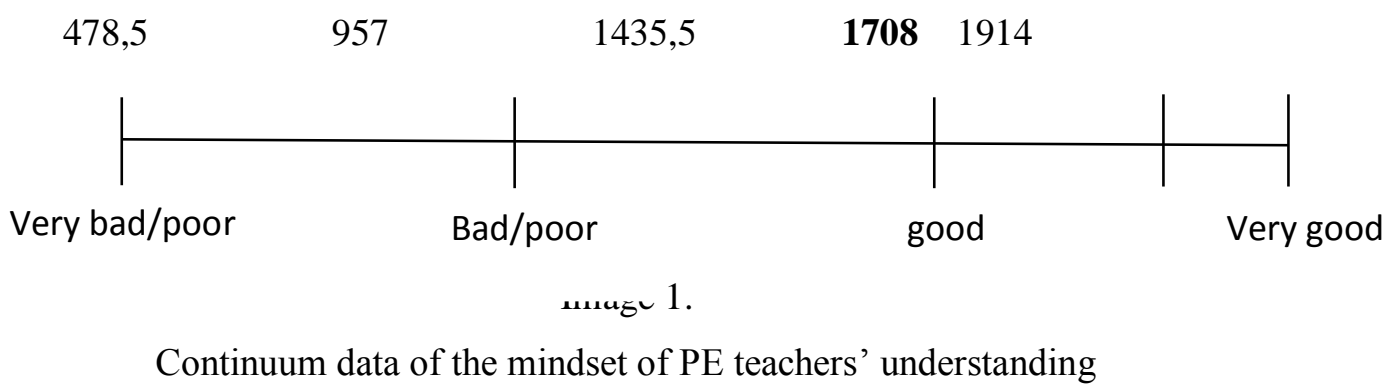

Based on previously elaborated continuum data of the mindset of PE teachers on their understanding of physical education, it can be concluded that the overall mindset of the PE teachers after $P L P G$ was completed is in a range of good to very good. The data of each indicator of the items is presented in finer getails as follows:

\section{a. Perception on physical education}

The data analysis result of 29 PE teachers' mindset on their understanding of physical education was retrieved from 7 perception items on the understanding of the concept of physical education with the score of each item ranging from 1 to 3 . The highest score for perception item on PE teaching was $=3 \times 7 \times 29=609$, and the minimum score was $=1 \times 7 \times$ $29=203$. Meanwhile, the data demonstrating that the perception items on physical education was 539. Based on such results, the perception items on PE teaching were reflected in the following continuum.

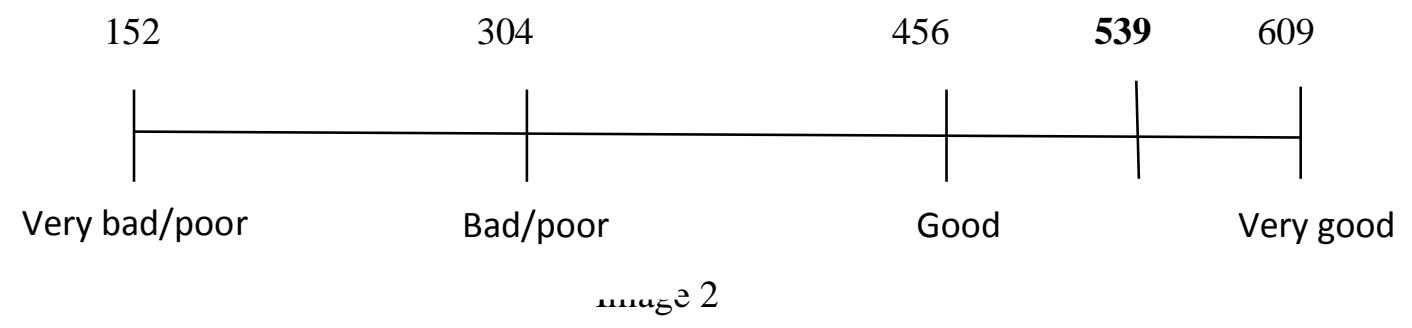

Continuum data on the perception of PE teaching 
Based on the data of the perception of physical education, it can be concluded that the perception of PE teachers after PLPG belongs in the range 'good'. Furthermore, based on the data, the percentage of the perception item on PE teaching was : $539 / 609 \times 100 \%=88,5 \%$ which is considered 'good'. Image 3 shows the distribution of the percentages of perception items on PE teaching.

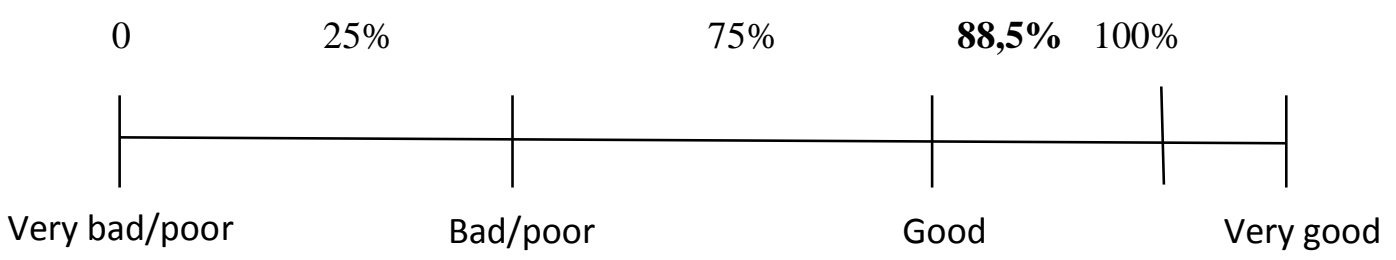

Image 3

The percentage distribution of the perception of PE teaching

In further details, the distribution of the frequency of perception scores on PE teaching is presnted in table 1 and image 4.

Table 1.

The distribution of the frquency of perception scores on PE teaching

\begin{tabular}{|c|c|c|c|}
\hline no. & interval & \multicolumn{2}{|c|}{ frequency } \\
\hline 1 & $14-15$ & 4 & $13,7 \%$ \\
\hline 2 & $16-17$ & 5 & $17,4 \%$ \\
\hline 3 & $18-19$ & 8 & $27,6 \%$ \\
\hline 4 & $20-21$ & 12 & $41,4 \%$ \\
\hline$\Sigma$ & & 29 & $100 \%$ \\
\hline
\end{tabular}

The diagram of the frequency distribution of the perception of PE teaching is presented as follows :

\section{The perception of the understanding of physical education}




\section{Image 4}

The diagram of frequency distribution of the perception of PE teaching

\section{b. Knowledge of physical education}

The data reveals 617 out of 698 that was resulted from the items on the knowledge of physical education. Based on such a result, the perception items on knowledge of physical education are presented in a continuum as presented in image 5.

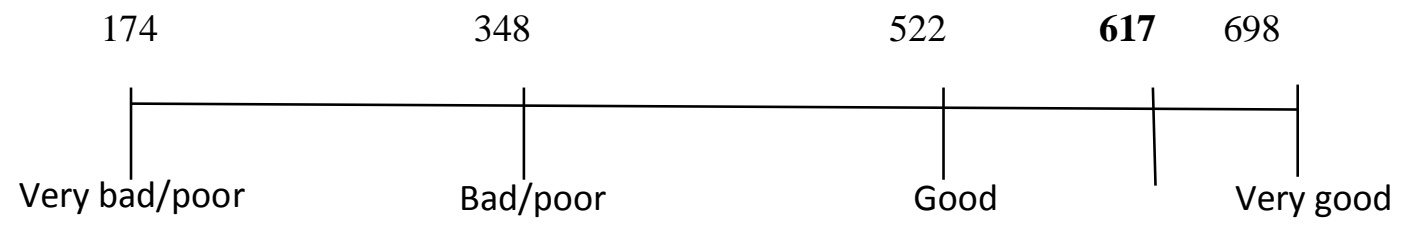

Image 5

Knowledge of physical education

Based the data on the knowledge of physical education, it can be concluded that the knowledge of physical education after the completion of PLPG is categorized in the range 'good'. The percentage of the items on the knowledge of physical education was : 617/698 $\mathrm{x}$ $100 \%=89,5 \%$ which belongs in the category 'good'. Image 6 illustrates the percentage distribution of the perception of PE teaching.

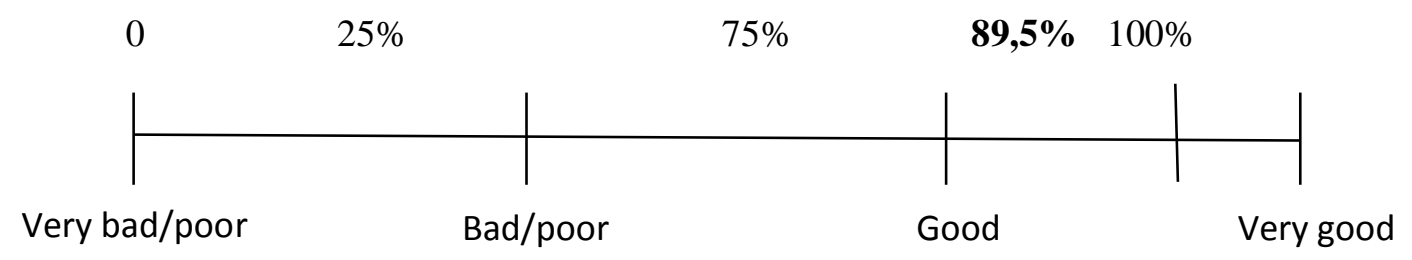




\section{Image 6}

Knowledge of physical education

The frequency distribution of the peception of PE teaching is presented in table 2 and image 6.

Table 2

Frequency distribution of perception scores on PE teaching

\begin{tabular}{|c|c|c|l|}
\hline no. & interval & \multicolumn{2}{|c|}{ Frequency } \\
\hline 1 & $16-17$ & 2 & $6,9 \%$ \\
\hline 2 & $18-19$ & 3 & $10,3 \%$ \\
\hline 3 & $20-21$ & 5 & $17,2 \%$ \\
\hline 4 & $22-23$ & 16 & $55,2 \%$ \\
\hline 5 & $24-25$ & 5 & $10,3 \%$ \\
\hline$\Sigma$ & & 29 & $100 \%$ \\
\hline
\end{tabular}

The diagram of frequency distribution on PE teaching is as follow :

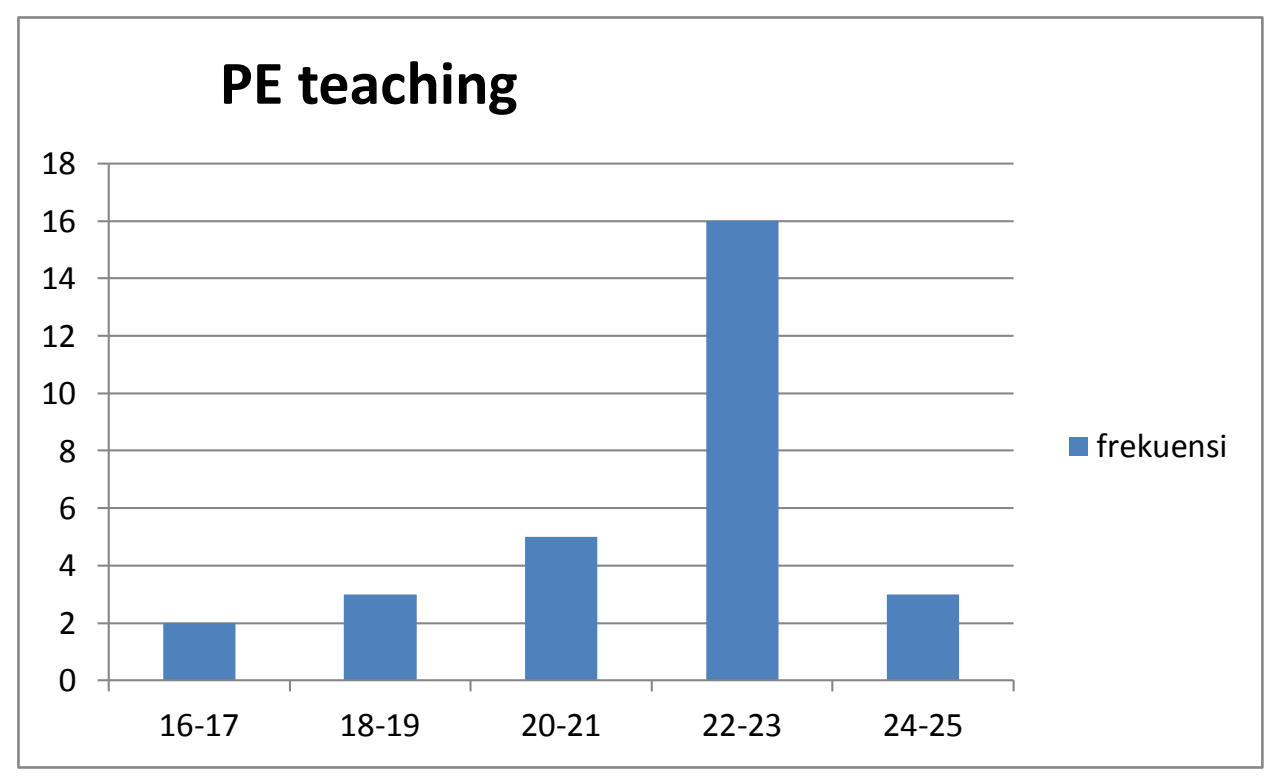


Image 7

PE teaching

\section{c. The effort to improve the ability on teaching PE}

The data shows that in the items of knowledge of physal education there were 552 out of 696 data. Therefore, the continuum is presented as follows.

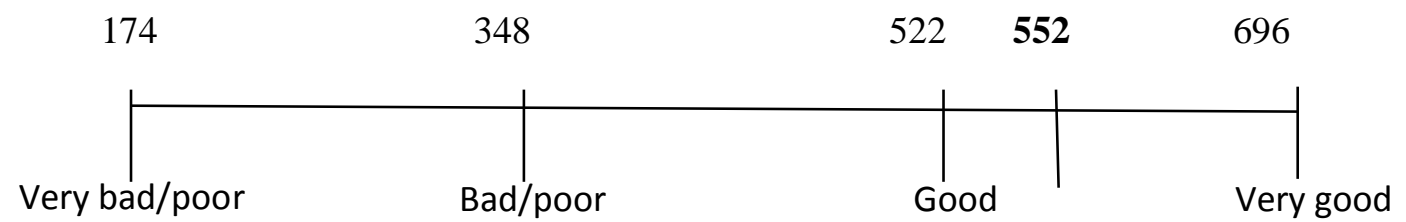

Image 8

The effort to enhance the ability in teaching PE

Based on the data, it can be concluded that the knowledge of physical education after the completion of $P L P G$ was categorized 'good'. As a result, the percentage for the items of enhancing the ability in teaching PE was : $617 / 696 \times 100 \%=79,3 \%$ which is considered as 'good'. Image 9 illustrates the percentage distribution of the effort to enhance the ability to teach PE.

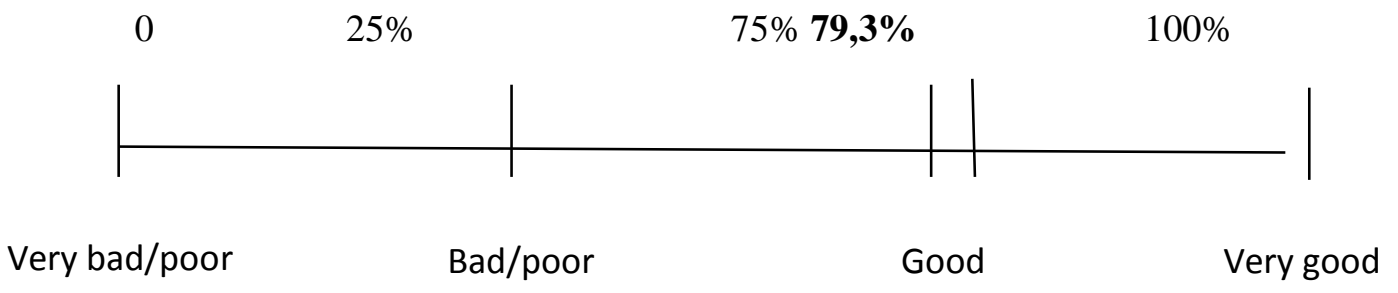

Image 9

The effort to enhance the ability to teach PE

The frequency istribution of perception scores on teaching PE is presented in table 3 and image 9. 
Tabel 3

The frequency distribution of the scores of the effort to enhance the aility in teaching PE

\begin{tabular}{|c|c|c|c|}
\hline no. & interval & \multicolumn{2}{|c|}{ frequency } \\
\hline 1 & $16-17$ & 4 & $13,8 \%$ \\
\hline 2 & $18-19$ & 17 & $58,6 \%$ \\
\hline 3 & $20-21$ & 8 & $27,6 \%$ \\
\hline$\Sigma$ & & 29 & $100 \%$ \\
\hline
\end{tabular}

The diagram of the frequency distribution of the effort to enhance the ability in teaching PE is exhibited as follows :

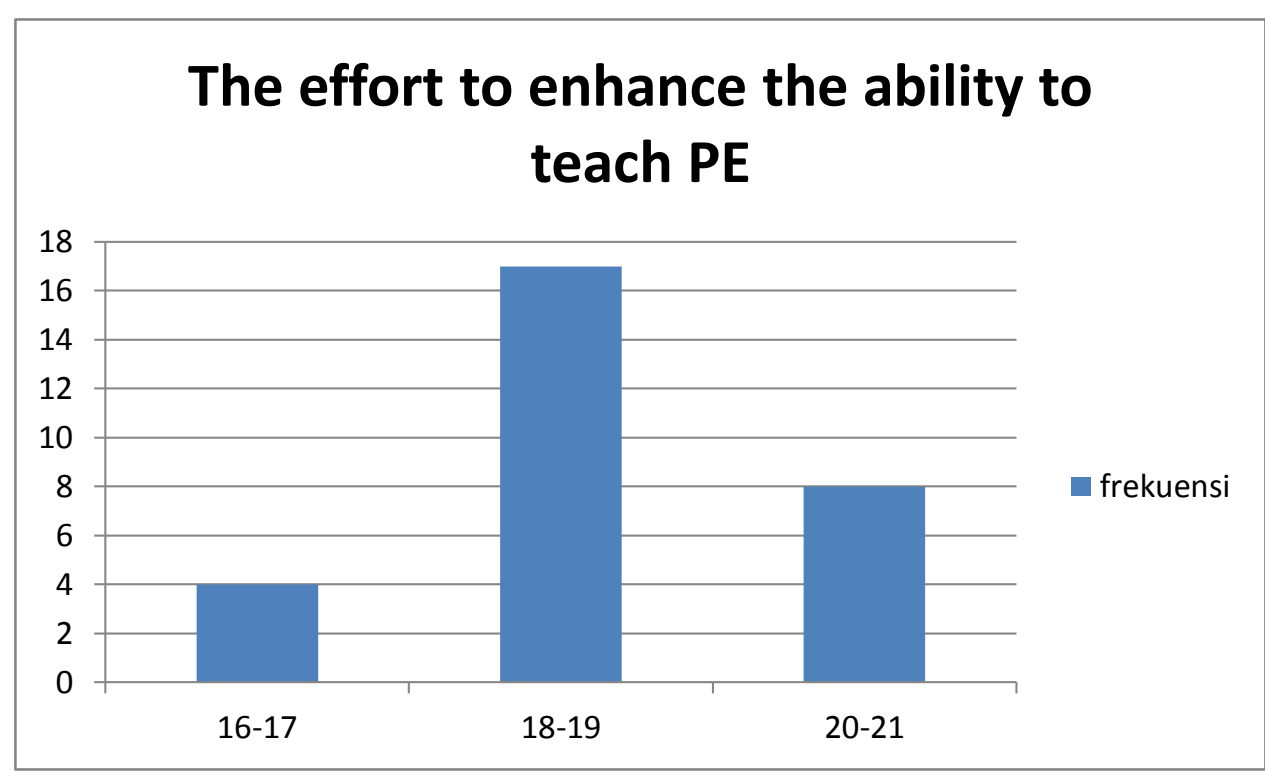

Image 10

PE teaching

\section{DISCUSSION}

Mindset in this study refers to the way of thinking that affects the way of working. In other words, mindset is an attitude of an individual that shows consistency between way of thinking/knowledge, abilities and behaviour. An individual who posseses such qualities will 
have the awareness or willing ness to accept and fight for such consistensy. In organizational context, it is called working culture.

Based on the findings, overall, the mindset of PE teachers in district 134 UNPAS on their understanding of physical education was represented as much as $88,5 \%$. Such a result indicates that the mindset of the teachers on their understanding of physical education is considered as good.

Professional teachers must possess a minimum academic qualification of a bachelor's degree or a diploma, must be able to acquire competency standards (social, professionalism, integrity, and pedagogy), must be physical and psychologically healthy, must own teacher certification, and must have a purpose to realize national education goals. The advantages of training to teachers among others are : (1) helping teachers to make better decisions; (2) enhancing the teachers' ability to solve problems they encounter; (3) facilitating internalization and operating motivational factors; (4) encouraging teachers to keep improving their working ability; (5) enhancing teachers' ability to cope with stress, frustration and conflicts which in turn boosting their sense of self confidence; (6) providing teachers with information on numerous programs that can be used by the teachers in order to nurture growth technically and intellectually; (7) enhancing work satisfaction; (8) recognizing one's ability; (9) encouraging teachers to be more autonomous; and (10) alleviating fear in facing new tasks ahead.

In terms of enhancing teachers' professionalism, especially PE teachers, Magliaro stated that If teachers are to be successful in emulating these tenets of reform, many will need to make major changes in their practices, knowledge and beliefs about teaching, learning, and subject matter. It means that when a teacher desires a change to gain more success, the changes need to be realized in terms of teaching practice, the knowing the benefit of posessing knowledge of teaching, learning and students' characteristics.

One of the measures that the government employ to realize such changes is by implementing PLPG, as stipulated in National Education's Ministry's regulation No. 18/2007. The participants of $P L P G$ are teachers who have not passed teacher certification program in portfolio assessment and they are recommended to join PLPG by Teacher Education Institution $(L P T K)$ as the institution in charge of teacher certification. 
The benefit that the teachers, especially PE teachers, gain after completing PLPG among others are improvement of their insight and knowledge in teaching, practising how to teach to other fellow teachers, learning how to write research paper, teaching modules and others.

During the implementation of $P L P G, \mathrm{PE}$ teachers are directed to change their mindset on physical education, particularly on the difference between physical education and sport in terms of implementation, equipment, development and accomplishment of teaching goals. A study conducted by Stobart, et. al. explained that as such, a framework for continuing professional development (CPD) should be designed to help teachers refine their knowledge and skills, especially since producing changes in classroom practice, from a perspective lifelong learning, seems to be a major challenge for the profession. Professional development programs such as $P L P G$ have to be design to help teachers refine their mindset on the knowledge and the ability to teach PE so that the implementation of PE at school will be aimed to develop the students' ability holistically. The implication of this research is that the implementation of PLPG has to focus on the improvement of understanding of the concept of physical education and the effort to refine the ability to teach PE in creative and innovative manner.

\section{CONCLUSION}

Based on the findings of this study, overall, the mindset of the PE teachers in district 134 UNPAS on their understanding of physical education after PLPG was considered 'good' as suggested by the percentage of $89 \%$ in their result of perception rating scale. It means that most of the PE teachers have changed their mindset on physical education interms of their perception on physical education, the knowledge on physical education and the effort to enhance their ability to teach PE.

\section{REFERENCES}

Ad-Duweisy, Muhammad Abdullah, Menjadi Guru yang Sukses dan Berpengauh, Terjemahan, judul asli : al-Madrasah wa al-Maharat al-Taujih, Surabaya : eLBA, 2005 , h. 37 
Day, C., Stobart, G., Sammons, P., Kington, A., Gu, Q., Smees, R., \& Mujtaba, T.Variations in teachers' work, lives and effectiveness (VITAE). Vol. 25, No. 1, Summer 2010. h. 43

Direktorat Profesi Pendidik, Diten PMPTK, 2005

Direktorat Profesi Pendidik, PMPTK, 2005

Idochi Anwar, Dasar-Dasar Statistika. Bandung: Alfabeta. 2006, h. 127

Malgiaro, susan, at.all. The Effect of Professional Development on Physical Education Teachers' Use of Assessment in the Classroom, Blackburg. 2007, h.9

Patrie, K \& Mcdee, C. Teacher Professional Development: Who is the learner?. Vol 37, 2, February 2012, h.59

Permen No. 18 tahun 2007 ,h.2

SKG, Direktorat Tendik 2003, h.3

Sugiyono, Metode Penelitian Pendidikan, Bandung: alfabeta, 210, h. 144

Suherman, Wawan. Peningkatan Profesionalisme Guru Penjas Orkes Melalui Sertifikasi, UNIBA: Banyuwangi, 2009. h. 2

Sutjipto, Jurnalnet, 2005, h.16

Undang-undang RI Nomor 14 Tahun 2005 